\title{
RECENT FINDINGS OF THE TYPES OF PROGRAMMED CELL DEATH
}

\author{
Sylwia BORYS ${ }^{1}$, Ronza KHOZMI ${ }^{1}$, Wiesława KRANC ${ }^{1}$, Artur BRYJA ${ }^{1}$, Marta \\ DYSZKIEWICZ-KONWIŃSKA², Michal JESETA ${ }^{3}$, Bartosz KEMPISTY ${ }^{1,4}$ \\ ${ }^{1}$ Department of Anatomy, Poznan University of Medical Sciences, Poland \\ ${ }^{2}$ Department of Biomaterials and Experimental Dentistry, Poznan University of \\ Medical Sciences, Poland \\ ${ }^{3}$ Department of Obstetrics and Gynecology, University Hospital and Masaryk \\ University, Brno, Czech Republic \\ ${ }^{4}$ Department of Histology and Embryology, Poznan University of Medical \\ Sciences, Poland
}

DOI: $10.1515 / \mathrm{acb}-2017-0004$

Summary: Cell death plays an important role in maintaining the homeostasis of multicellular organisms. It can occur in a controlled manner by apoptosis or autophagy. Cell death which occurs regardless of regulatory factors include necrosis, mitotic catastrophe or oncosis.

Apoptosis and necrosis are cellular process that leads to cell death. However their mechanisms are different, although factors triggering them can be similar. Necrosis and apoptosis have many different characteristics in terms of biochemistry and morphology.

There are two main pathways of apoptosis induction signal: receptor - dependent and mitochondrial. The outsider apoptotic pathway is induced by external factors stimulating membrane receptors having an intracellular domain called death domain.

Mitochondrial apoptotic pathway is activated by increased concentration of reactive oxygen species (ROS), DNA damage, disorders electrolyte transport and an increase in the concentration of the calcium ions in the cytoplasm. In response to stress-factors, mitochondrial channels are opened, so that is released into the cytoplasm cytochrome $\mathrm{C}$. This work is aimed at an overall description of exchanged processes.

Keywords: apoptosis, necrosis, mitochondrial apoptosis pathway, receptor-dependent apotposis pathway 


\section{INTRODUCTION}

Apoptosis is the best known form of programmed cell death. It is a physiological process which conditions the proper functioning of the body from the embryonic phase to its death. It is characterized by a very orderly course - the activation of a number of specific biochemical pathways leading to the end of cell's life. Anoicosis is a type of apoptosis occurring in adherent cells as the result of the loss of adhesion to substrates or to other cells.

Autophagy is the second type of programmed cell death. Such a mechanism is activated under stress conditions, e.g. in the absence of sufficient amounts of nutrients or as the result of damage caused by cell toxins. In this process, the changed (damaged or unnecessary) cytoplasmic proteins or whole organelles are closed in vacuoles, so-called autophagosomes. In the next stage, they are transported to the lysosomes, where they undergo degradation [9].

Necrosis occurs primarily in pathological conditions. It is characterized by uncontrolled biological pathways inactivation, denaturation of proteins, release of lysosomal enzymes, cytoplasmic swelling and disintegration of a cell. All these processes lead to severe inflammatory lesions.

Oncosis is an unprogrammed type of cell death that is mostly initiated by the mitochondria. In literature, the concept of oncosic and necrosis are often used interchangeably.

The imprecise process of mitotic division can lead to cell death, known as mitotic catastrophe. As the result of improper functioning of checkpoints in the cell cycle, there occurs the abnormal segregation of chromosomes into daughter cells. This results in the creation of cells which contain two or more nuclei $[6,10,3]$.

\section{CELL APOPTOSIS}

Apoptosis is so-called programmed cell death, which is a very important mechanism in the development and functioning of multicellular organisms to control the number of cells in the body. This term was first introduced by Kerr and his colleagues in 1972 [9]. In the second half of the 20th century there was a flowering of research on apoptosis. The results of research showing the complexity of the process and its significant role in the course of carcinogenesis contributed to intensification of research on cell death among many scientists around the world.

Apoptosis always occurs in an orderly manner. The first stage concerns changes at the cell nucleus level leading to chromatin condensation and subsequently to its shrinking and fragmentation. In the next stage, there occurs the shrinkage of 
the cytoplasm and the creation of characteristic bulges of cell membrane which create the apoptotic bodies. They contain condensed chromatin, the cytoplasm and functional organelles. The final stage of the apoptosis is the phagocytosis of the new bodies by the neighbouring cells or macrophages $[10,2]$.

\section{APOPTOSIS AND NECROSIS - A TWO TYPES OF PROGRAMMED CELL DEATH}

Necrosis and apoptosis have many different characteristics in terms of biochemistry and morphology. Apoptosis is a process that mostly occurs physiologically. Necrosis, however, is usually a pathological process. Necrosis which physiologically occurs in the peeling of the uterus mucous membrane during the menstrual cycle is an exception. The initiation of the apoptosis process requires the activation of many biochemical pathways and the formation of various proteins. That is why, on the contrary to necrosis which is passively activated by exogenous factors, this is an active process. Apoptosis normally takes place independently in the individual cells of a tissue. Necrosis, however, occurs in a massive and rapid manner which results in extensive inflammation processes. In necrotic cells there occurs swelling, which leads to a cell membrane disruption and a spill of the cytoplasm content to the extracellular space. Despite the apoptotic cells shrink and their cell mambranes undergo multiple bulges due to the hydrolysis of sphingomyelin, they still maintain continuity $[12,1]$. Thus, from such a cell there arise many apoptotic bodies which are then phagocytosed.

At the biochemical level, in the cell directed to the process of necrosis, there occurs the release of lysosomal hydrolases which digest cellular organelles. As the result of the protein denaturation, many enzymes are deactivated, and the cellular DNA is broken into fragments of random lengths. In the cells which undergo apoptosis, only some of the biochemical pathways are activated which leads to proteolysis of some cellular organelles. The DNA is in the form of condensed chromatin and is cut into pieces of a fixed base pairs (180-200) and their multiples [2].

\section{THE MAIN MECHANISM OF APOPTOSIS INDUCTION}

Apoptosis undergoes the initiation due to various factors. These include: ionizing radiation, photodynamic therapy, the activation of so-called death receptors, oxidative stress, certain medications and too low level of growth factors. In general, they cause DNA damage and cell cycle progression disorders [1]. 
Caspases, which belong to the family of cysteine proteases, constitute a link between various transduction pathways of the apoptosis signal in cells. They can be activated in several alternative ways: through the release of cytochrome a from a mitochondrion, the activation of the so-called death receptors, the stress of an endoplasmic reticulum and as the result of a $\mathrm{B}$ granule-associated enzyme activity [8]. They show their activities by hydrolysis of C-peptide final bonds and the rest of aspartic acid. There are three groups of caspases: initiator 2, 8, 9, 10, executioner 3 , 6,7 and also inflammatory $1,4,5$, which are involved in the inflammation process. Caspases are formed as inactive pro-enzymes in the cytoplasm. Activation, which generally depends on other caspases, occurs as the result of proteolysis, which results in two chains such as a short and a long one. The prodomain is discarded. Initiator procaspases contain a recruitment domain of caspase recruitment domain (CARD), which is involved in the creation of the activation complexes: the apoposome in the intrisic pathway and death-inducing signaling complex (DISC) in the extrinsic pathway. Procaspases included in the DISC and an apoposome are activated in the autocatalytic manner and the executioner procaspases are activated with the help of the initiator Caspases [8]. Caspases have the inactivation ability such as inhibitor of caspase activated DNAse (ICAD), which leads to the activation of caspase activated DNAse (CAD) leading to the DNA fragmentation, which is characteristic of the apoptosis process [2].

There are two types of factors that activate the apoptosis process: intracellular and extracellular [9]. The endogenous causes of the apoptosis activation include: anoikis and damaged DNA leading to the activation of the mitochondrial pathway. The extrinsic pathway is initiated by the activation of "death receptors".

There are many types of apoptosis signal pathways. The pseudoreceptorial pathway identified in T and NK cells (natural killer) occurs with the assistance of perforine and granzyme B (GrB). Ionizing radiation, lack of growth factors and viral infections can place the cell on the sphingomyelino-ceramide pathway of apoptosis. Stress induced pathway is related to the endoplasmic reticulum. Its activation occurs as the result of abnormal calcium ions as well as the presence of structurally proteins in the endoplasmic reticulum [10].

\section{RECEPTOR - DEPENDENT APOPTOSIS PATHWAY}

The extrinsic apoptotic pathway is activated by the stimulation of membrane death receptors by external factors, cytotoxic $\mathrm{T}$ lymphocytes, and the integration of membrane proteins Fas and FasL in the same cell [7]. The death receptor DRS (death receptors) include protein receptors of the necrosis factor - TNF receptor (tumor necrosis factor). DRs include: TNFR-1, TNRF-2, TRAIL (Apo-1), Fas 
(Apo-1, CD95). DRs consist of three parts: extracellular (which has the ability to bind ligands), transmembrane and cytoplasmic (which has a death domain, DD). Ligand binding leads to the trimerization of DD [2]. This facilitates the binding of the protein adapter such as Fas-associated death domain (FADD) and TNFR-1 associated death domain (TRADD) to DRs [5]. They have their own domain DD, which allows a receptor to integrate with DD as well as the death effector domain (DED) , which has the ability to join procaspase 8 and/or 10. As the result of the above-described inclusion, a death inducing complex is formed (DISC). The DISC complex initiates a cascade of caspases which cause the death of a cell [2]. The extrinsic pathway can secondarily activate the mitochondrial pathway by the Bid protein, which is a substrate for caspase 8 . As the result of its proteolysis, the protein tBid is created, which is an active form. As the result of tBid activity, the anti-apoptotic Bcl-2 and Bcl- $\mathrm{X}_{\mathrm{L}}$ are blocked, which leads to the oligomerisation of $\mathrm{Bax}$ and Bak. The release of cytochrome $\mathrm{c}$ from the mitochondria, which results in the initiation of the intrinsic pathway, is the effect of the previously mentioned cascade change [14].

\section{MITOCHONDRIAL APOPTOSIS PATHWAY}

The intrinsic pathway of apoptosis is mediated by mitochondria. The initiation of this process occurs as the result of DNA irregularities, an increase in the level of ROS, electrolytes transport disruption, an excessive level of oxidative stress and an increase in the $\mathrm{Ca}^{2+}$ ion concentration in the cytoplasm [10]. The reason of the activation of this pathway could be also be the distortion of the contact between cells or with the extracellular matrix, which leads to the anoikis type apoptosis [11].

Upon initioation, the mitochondrial channels open and the release approximately 40 different proteins from the intermembrane mitochondria space. One of these proteins is cytochrome c (Apaf-2) which, after getting into the cytoplasm, is integrated with apoptosis protease activating factor (Apaf-1). At its $\mathrm{N}$-terminus, Apaf-1 has a capsize recruitment domain (CARD), which has the ability to bind procaspase 9. The integration of cytochrome c, Apaf-1 and procaspase 9 forms a circular heptameter called apoptosome. It shows the ability of autocatalytic procaspase 9 and caspase 9 activation, which is called the mitochondrial pathway caspase initiator. It has the ability to activate the executioner caspase cascade, which leads to cell death $[2,4]$.

Bcl-2 protein family is the best known heterogeneous group which regulates the mitochondrial apoptotic pathway. It affects the transport of the proteins which are the apoptosis regulators, i.e. the cytochrome c, Omi/Htr 2 protein and Smac/ 
DIABLO from the mitochondrion interior to the cytoplasm. One feature of this protein family is having the $\mathrm{BH}(1-4)$ domain. The amount and a type of a domain present allows certain protein to be classified to a certain group. The group of antiapoptotic proteins have four domains: Bcl-2, Bcl- $\mathrm{X}_{\mathrm{L}}$ and A1/Bfl-1. The second group consists of the pro-apoptotic proteins which have three domains BH123, i.e. Bax and Bak, and one BH3 domain, i.e. Bid, Bim, Bad and Puma [15].

Stress conditions and genome damage can activate the pro-apoptotic protein $\mathrm{p} 53$, which is known as the guardian of the genome. As the result of the displacement to the mitochondrion, it has the ability to activate the apoptosis intrinsic pathway. Such an activation occurs as the result of the p53 protein and $\mathrm{Bcl}-2 \mathrm{H} \mathrm{Bcl}-\mathrm{X}_{\mathrm{L}}$ proteins connection, which results in the release of cytochrome $\mathrm{c}$ into the cytoplasm, and then the initiation of the caspases cascade [4].

\section{ACKNOWLEDGEMENTS}

Publication of this article was made possible by grant number 502-14-0222736710694 from Poznan University of Medical Sciences

\section{REFERENCES}

[1] Chwilkowska A, Kulacka J, Saczko J. Śmierć komórek nowotworowych. Udział reakcji fotodynamicznje w indukcji apoptozy w komórkach nowotworowych. Pol. Merk. Lek. 2011; 30 (175): 45-48.

[2] Kawiak J, Zabel M. Seminar ia z cyt ofizjol ogii, Elsevier Urban \& Partner, Wroctaw 2014, 73-80.

[3] Kwiecińska-Piróg J, Prażyńska M, Reśliński A, Gospodarek E, SzczęSny W, Dąbrowiecki S. Wpływ pałeczek Shigella sp. na śmierć komórki eukariotycznej. Post. Mikrobiol. 2010; 40 (1): 33-41.

[4] Łabędzka K, Grzanka A, Izdebska M. Mitochondrium a śmierć komórki., Postepy Hig Med. Dosw. (online) 2006; 60: 439-446.

[5] MacEwan DJ. TNF receptor subtype signaling: Differences and cellular consequences, Cellular Signalling. 2002; 14: 477-492.

[6] Patкowski J, Wytrychowski K. Patofizjologia apoptozy i jej znaczenie w rozwoju zapalenia alergicznego i chorób alergicznych. Adv. Clin. Exp. Med. 2006; 15 (2): 321-328.

[7] Pedrycz A, Siermontowski P, Lonc G, Tomasiak M. Zewnętrzna droga indukcji sygnału do apoptozy: receptory śmierci, Polish Hyperbaric Researc. 2012; 4 (41): 147-157.

[8] Riedl SJ, Salvese GS. The apoptosome: signalling platform of cell death. Nature Rev. Mol. Cell Biol. 2007; 8:405-413.

[9] Rudnicka KW, Szczęsna E, Miszczyk E, Mikolajczyk-Chmiela M. Apoptoza i autofagia- mechanizmy i metody detekcji. Postępy biologii komórki. 2011; 38 (2): 247-265.

[10] StęPień A, Izdebska M, Grzanka A. Rodzaje śmierci komórki. Postepy Hig. Med. Dosw.(online) 2007; 61: 420-428.

[11] TaIt SWG, Green DR. Mitochondria and cell death: outer membrane permeabilization and beyond, Nature Rev. Mol. Cell Biol. 2010; 11: 621-632. 
[12] Tepper AD, Ruurs P, Wiedmer T, Sims PJ, Borst J, Van Blitterswijk WJ. Sphingomyelin hydrolysis to ceramide during the execution phase of apoptosis results from phospholipid scrambling and alters cell-surface morphology. J. Cell Biol. 2000; 150: 155-164.

[13] Ulukaya E, Acilan C, Yilmaz Y. Apoptosis: why and how does it occur in biology? Cell Biochem. Funct. 2011; 29: 468-480.

[14] Van Mau N, Kajava AV, Bonfi ls C, Martinou JC, Harricane MC. Interactions of Bax and tBid with lipid monolayers, J. Membr. Biol. 2005; 207: 1-9.

[15] Youle R, Strasser A. The BCL-2 protein family: opposing activities that mediate cell death, Nature Rev. Mol. Cell Biol. 2008; 9: 47-59.

Editor -

Bartosz Kempisty

Department of Histology and Embryology, Department of Anatomy

Poznań University of Medical Sciences

6 Święcickiego St., 60-781 Poznań, Poland

tel./fax: +48618546418/+48618546440

e-mail: bkempisty@ump.edu.pl 